J.-P. COLlin, * F. DUROLA, J. FREY, V. HEITZ,* F. REVIRIEGO, J.-P. SAUVAGE,*

Templated Synthesis of Cyclic [4]Rotaxanes Consisting of Two Stiff Rods Threaded through Two Bis-macrocycles with a Large and Rigid Central Plate as Spacer

J. Am. Chem. Soc. 2010, 132, 6840-6850.

Synthesis of

Materials and

Unnatural Products

\title{
A Cyclic [4]Rotaxane
}

\section{Key words}

rotaxanes

click chemistry

macrocycles

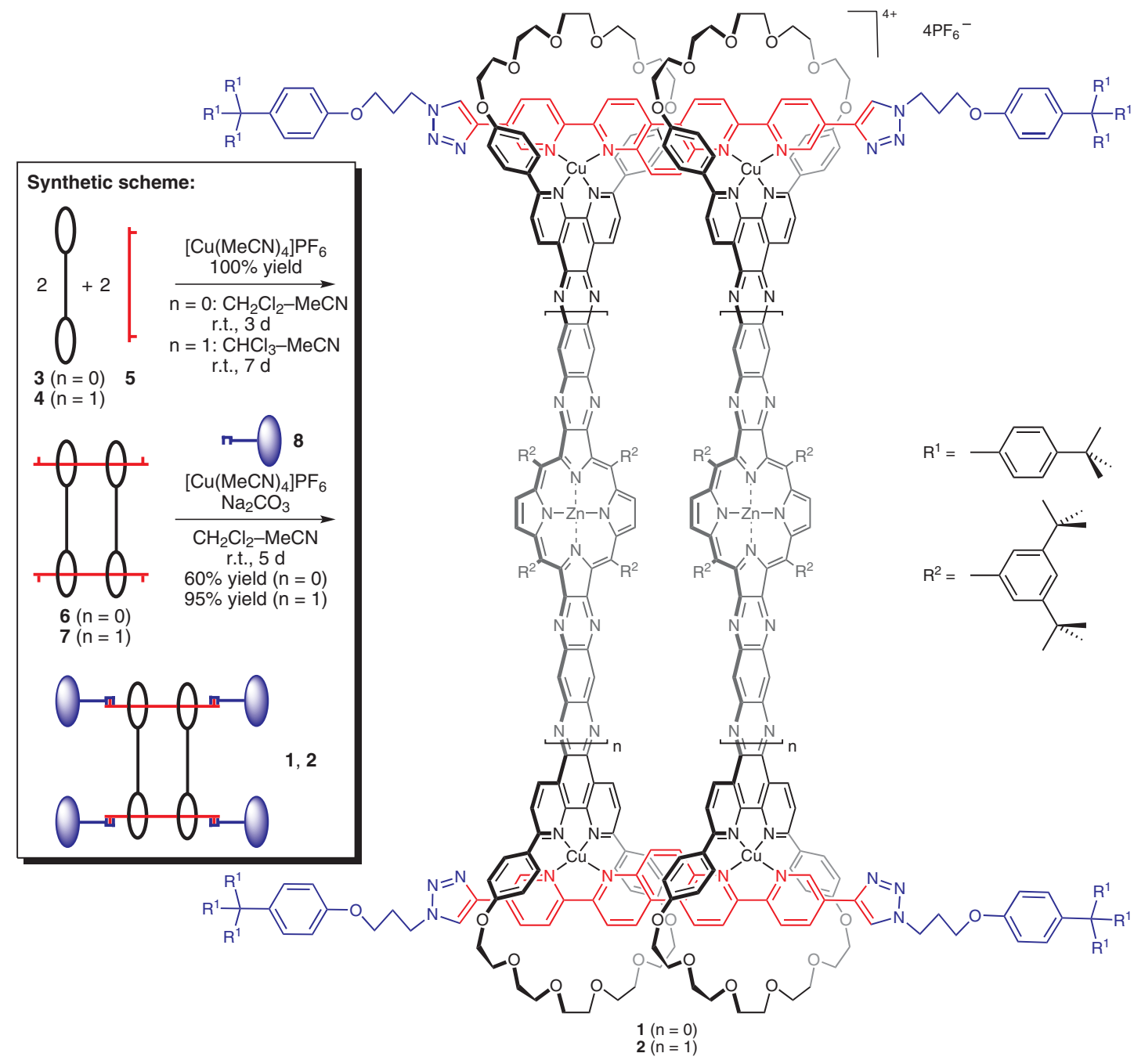

Significance: The authors synthesized the two cyclic [4]rotaxanes $\mathbf{1}$ and $\mathbf{2}$. The structure of $\mathbf{2}$, containing zinc porphyrin units, was determined by $\mathrm{X}$-ray crystallography and is the largest rotaxane molecule characterized in this way.
Comment: The synthetic strategy includes the quantitative copper-driven assembly and threading of $\mathbf{5}$ through the macrocycles $\mathbf{3 , 4}$ and the attachment of stoppers $\mathbf{8}$ by click chemistry in high yields. Compound $\mathbf{2}$ was tested as a receptor for ditopic guests in complexation studies. 